\title{
A model for agricultural research
}

\author{
C.A. Bisschoff* \\ Department of Business Economics, University of Pretoria, Pretoria 0001, Republic of South Africa
}

\author{
A. de K. Marais
}

Department of Business Economics, University of South Africa, P.O. Box 392, Pretoria 0001, Republic of South Africa

\author{
M.J. van Reenen
}

Department of Business Economics, University of South Africa, P.O. Box 392, Pretoria 0001, Republic of South Africa

\author{
Received April 1993, accepted March 1994
}

\begin{abstract}
In this article we report on a newly developed agricultural marketing research model. The development of such a model proves to supply future researchers the opportunity to employ this model in their research. This model enables the researcher to analyse more than one set of respondents within the same research structure, while comparative analyses could also be performed between the groups of respondents. The model consists of four stages, namely: establish relevant criteria; individual statistical analysis of the criteria; comparative analyses; and results and findings. Each of the four stages of the model is discussed according to the methodology used and the expected results of each stage. Warnings and procedural prescriptions are offered within each stage of the model, and checkpoints are also built in to ensure that a user of the model would not proceed towards the next stage if the previous stage was not executed satisfactorily. The benefit of the research model is that it supplies a structured framework which could be employed by future agricultural researchers to perform related research projects. The model could also be employed as a basis from which other researchers could alter or create their own research methodology since limited research has been conducted in the discipline of agricultural marketing research process.
\end{abstract}

In dié artikel word verslag gedoen oor 'n nuut ontwikkelde landboubemarkingsnavorsingsmodel. Die model kan soos in die artikel voorgestel, gebruik word, of as basis vir die konstruksie van ander landboubemarkingsnavorsingsmodelle dien. Die landboubemarkingsnavorsingsmodel stel navorsers in staat om meer as een groep respondente binne dieselfde navorsingstruktuur te analiseer terwyl vergelykende analise tussen die groepe respondente ook moontlik gemaak word. Die landboubemarkingsnavorsingsmodel bestaan uit vier fases, naamlik: bepaling van die relevante evalueringskriteria; individuele statistiese analise van die kriteria; vergelykende analise; en resultate en bevindings. Elk van die vier fases van die model word bespreek volgens die metodologie wat gebruik is en die resultate wat van elke fase verwag kan word. Waarskuwings en prosedurale voorskrifte word voorsien gedurende elke fase en toetsprosedures word voorgestel om die gebruiker van die model te waarsku indien daar nie voortgegaan kan word na die volgende fase van die model nie. Die voordeel van so 'n landboubemarkingsnavorsingsmodel is dat 'n gestruktureerde raamwerk voorsien word aan toekomstige landboubemarkingsnavorsers vir gebruik in hul eie navorsing, en dat verwagte resultate geformuleer kan word deur die gebruikers van die model. Die model kan ook as basis vir die formulering van eie navorsingsmetodologieë gebruik word aangesien beperkte navorsing in landboubemarkingsnavorsingsprosedures tot op hede gedoen is.

*Author to whom correspondence should be addressed.

\section{Introduction}

The decision to develop an agricultural marketing research model is subject to certain constraints such as limited formal research structures and few developed statistical models which could be employed to analyze the data. Laubscher (1990: 203-204), in this regard, suggests that marketing research in the agricultural sector be developed into a management decision tool and that multi-diciplinary agricultural research be extended in the future. The development and formulation of a research methodology to analyze the actions of role players in the agricultural marketing, therefore, seems to be a necessity if it is endeavoured to analyze the market for capital goods in the agricultural sector of marketers and buyers who have to deal with quantitative and qualitative information processing. In this article we report on the formulated agricultural research model which was developed to analyze multiple role players within the market for capital agricultural goods. The methodology can also be easily employed by other researchers if they enter into marketing rescarch in the agricultural sector and other relevant research disciplines.
The article is commenced by, firstly, supplying a short theoretical review of possible relevant research. Secondly, presenting the research model as an entity, thus presenting it as a process which can be employed by agricultural marketing researchers to conduct related research accordingly to the prescribed model. Thirdly, the various stages in the marketing research process are discussed according to the advantages of the prescribed research model, and warns against the pitfalls which exist within each stage. Fourthly, the results which could be expected from the prescribed research model employed, are highlighted. The model was also tested in the mechanized irrigation industry (Bisschoff, 1989) and in the agricultural tractor market (Bisschoff, 1992), and proved to be successful in supplying useful information to marketers and buyers of these capital products.

\section{Theoretical base}

Agricultural models are frequently employed, locally and internationally, to the benefit of managers and decisionmakers in agriculture. A few examples such as the usage of models in the determination of groundwater afforestation 
(Kienzle \& Schultze, 1992: 265), decision-making models in poultry management (Voros \& Manos, 1993: 232) and farm management models (McGrann, 1993: 254) are generally found to be useful. The basic question revolves around the very litule formal research work which has been conducted on the topic of agricultural marketing. Therefore, in order to develop an agricultural marketing research model, the research performed in marketing research and consumer behaviour serve as a basis for a research model applicable to the agricultural sector.

Du Plessis (1986) formulated a consumer-orientated research model for the use in the purchase process of new vehicles. Using this research model as a base, Bisschoff (1989) tested part of it in the agricultural sector by analyzing customer behaviour and preferences in the mechanized irrigation industry. The results obtained in this analysis were consistent with expectations derived from studies by Van der Walt (1989) and Du Plessis (1987). Rousseau (1992: 67) performed a study on identifying a model of consumer awareness criteria. This research served as a guideline to structure the initial list of criteria for the agricultural model of marketing research being reported on, while the replacement purchases of farmers received inputs from the study by Coetsee \& Viljoen (1990: 257). These studies, in addition to Bisschoff (1992) and Du Plessis (1986), served as the base for the consumer/customer part of the newly developed model.

The marketer part of the model is addressed by analyzing the contemporary research by Du Plessis (1986), Machethe (1990: 305), Bisschoff (1992) and the Sheth model of industrial buying behaviour (Botha \& Loubser, 1984: 281). Strategic managerial issues such as marketing, finance and agribusiness research (Hough, 1993:6-9) are incorporated in the supplier part of the model.

The comparative results of the newly developed model provided little literature apart from the studies performed by Du Plessis (1986) and Bisschoff (1992).

With this article, therefore, we set out to provide a framework which could be employed to aid future researchers in their determination of an appropriate agricultural marketing research tool. In setting out this framework as a research tool, the future researchers are enlightened about the results which could be expected if they employ the prescribed model. The supplied research framework model also serve as a basis from which an altered statistical framework could be developed in accordance to the objectives of the article the future researcher wants to achieve.

\section{An agricultural marketing research model}

This marketing research model is employed during four stages. The first stage consists of the establishment of the evaluative criteria relevant to the market being researched. The second stage consists of the statistical analysis, pertaining to each of the individual samples participating in the research project, and determines to what extent the different samples deem these criteria to be important. In the third

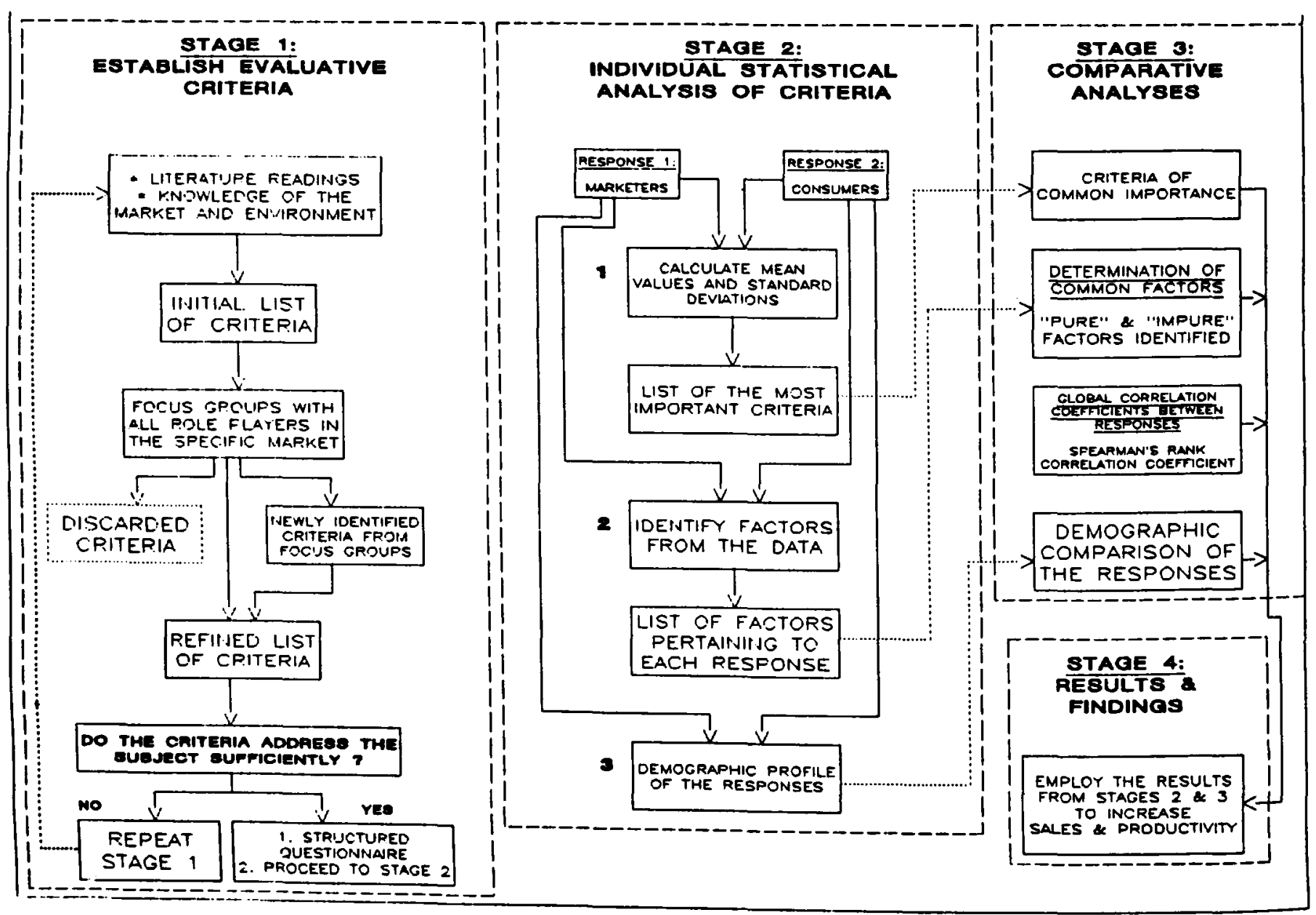

Figure 1 Agricultural marketing research methodology 
stage, the comparative analyses are conducted from the results obtained from the individual analyses in stage two of the research process. The fourth stage relates to the results and findings of the mentioned research model (see Figure 1).

\section{Stage 1: Establish evaluative criteria}

Stage 1 , the establishment of relevant criteria is certainly one of the most important stages in a research model (Rousseau, 1992: 67) because if the relevant criteria are not determined successfully, the results of the research project could not be of a high standard (Bisschoff, 1989: 103). This is the result of the fact that even if all three the other stages are performed almost perfectly, the results would be of an inferior quality because the identified criteria do not successfully address the market which is evaluated (Du Plessis, 1987: 176-177).

\section{Initial list of criteria}

In attempting to determine the relevant criteria applicable to the research project, a great deal of relevant literature should be read and researched (Botha \& Loubser, 1984: 90-91). In addition, hereto a thorough knowledge of all the participants of the specific market and its environment should be obtained. The initial research, through innovative and creative thinking (Williams, 1982: 278-279), ought to lead towards the identification of certain evaluative criteria which might seem important during the buying and selling behaviour of the role players relevant to the research project. This initial list of criteria presents the first pitfall in the research model. Although these evaluative criteria seem to be the important ones pertaining to the role players in the market, they should be tested through focus-groups to establish how important the role players in the market perceive these evaluative criteria (Bisschoff \& Marais, 1993: 32). Shown in Figure 1 are all the relevant stages of the research model.

\section{Refined list of evaluative criteria}

An appropriate method to test the identified criteria from the initial list, is to subject the list of criteria to discussions with focus groups pertaining to the market (Bisschoff, 1989). It is important not to exclude some of the role players from the focus-group discussions. An example of such a pitfall could be to discuss the initial list of criteria with only one focusgroup, and because these discussions were to substantiate the list of criteria, not to discuss it with the other role players. Such an error could be the exclusion of either one of the groups of important role players from the focus-group discussions which could cause important evaluative criteria not to be identified, and thus omitted from the research (Bisschoff, 1992: 281). An omission of this nature could result in the deteriorating quality of the results.

The focus-group discussions should result in new evaluative criteria being identified, while other criteria could be discarded as irrelevant to the research. Logically, these corrections to the initial list of evaluative criteria result in a refined list containing the new evaluative criteria. Once the researcher is satisfied that the refined list of identified evaluative criteria covers the subject successfully, and corresponds with the focus-groups' perceptions, the structured questionnaire could be drafted. Shown in Figure 1 is the fact that if the evaluative criteria unsuccessfully address the subject, more information will be required (Botha \& Laas, 1984: 47-48). The process, therefore, starts all over again with additional research. This feedback continues until the relevant evaluative criteria are determined (the feedback in Figure 1 is shown in dashed lines).

As shown in Figure 1, the first stage of the research model thus consists of the construction of the initial list of evaluative criteria compiled from literature research activities. The list of evaluative criteria are refined after focusgroup discussions and subsequent drafting of a structured questionnaire (Bisschoff, 1989). The structured questionnaire is presented to all the respondents in the selected samples pertaining to the proposed research.

\section{Stage 2: Individual statistical analysis of the criteria}

The analysis pertaining to the importance of the criteria commences only after data is collected from the completed structured questionnaires. The second stage analyzes the different samples in the research project individually, and similar analyses are thus performed on each of the samples. Although Figure 1, for the sake of simplicity, shows the research model with regard to only two samples, the number of participating samples are irrelevant since they are all handled in the same manner.

\section{Identify the most important criteria}

The analysis pertains to the determination of the more important individual criteria. This is done by calculating the mean values and standard deviation values for all the evaluative criteria employed in the structured questionnaire (Bennet, 1992: 35). Once the calculations are completed, the criteria with the highest mean values and the lowest standard deviation values are ranked in order of importance (Landy \& Trumbo, 1980: 23-25; Bennet, 1989: 472). The mean value serves as the primary determination variable, while the standard deviation serves as a secondary determination variable (Du Plessis, 1986: 277-278). The number of evaluative criteria identified as the more important criteria are subjected to the objectives of the research project and the choice thereof resides with the researcher (Bisschoff, 1992: 258).

\section{Identify factors from the data}

The analysis also includes the statistical procedure called 'factor analysis'. The data is thus subjected to a factor analysis which determines the underlying dimensions or factors existing within each sample's perceptions of the evaluative criteria (Le Roux \& Olivier, 1992: 57). These factors are labelled appropriately, while their variance and cumulative variance explained are also calculated (Luck, Wales, Taylor \& Rubin, 1982: 449-450). A cut-off factor loading with a specific absolute value is set to discard the less significant factor loadings, and to limit the number of criteria in the analysis (Van der Walt, 1989: 51). The number of factors which are extracted from the data could not be prescribed beforehand, since the results obtained from the data determines the number of identified factors 
(Botha \& Laas, 1984: 131). The cumulative variance explained by the extracted factors serve as a basis, and the cumulative variance should exceed the 50\% mark (Boyd, Westfall \& Stash, 1985: 642). Since it could be that the first five factors from one sample exceed the $50 \%$ mark while the other sample only manages to do so after eight factors have been extracted, the samples could differ in their number of identified factors. In such circumstances of a different number of factors, the researcher should not perceive this difference as a deterioration in the quality of the results, but should rather attempt to examine the individual factors more closely, since the participants in one sample could have been more precise in their perceptions than in the other sample (thus identifying two or more factors from a specific range of criteria, while the other sample identified only one factor) (Bisschoff, 1992: 261).

\section{Demographic profile of the participating samples}

The demographic profiles of the samples are drawn to ensure that a demographic picture of the participating respondents could be formulated (Bisschoff, 1992: 271; Rousseau, 1992: 75). Although not a vital part of the statistical analysis, handy information could result from such an analysis. The categories of the demographic comparison could not be structured since the emphasis thereof pertains to the objectives of the research and the researchers' particular needs with regard to demographic information (Rousseau, 1992: 74). However, the inclusion of the ages and educational levels of the participating respondents always seem to supply handy information with regard to the demographic profile of the respondents.

Stage two, as indicated in Figure 1, consists of the statistical analysis of the data, and includes the determination of the more important criteria, the identification of the underlying factors and the demographic profiles of the respondents. These processes must be repeated for every individual sample participating in the article, independent of the number of participating samples.

\section{Stage 3: Comparative analyses}

The third stage of the marketing research process consists of the comparative analysis of the results obtained from the second stage. The comparative analysis includes the comparison of the identified more important criteria, the factors pertaining to the different samples, and also the demographic profiles of the respondents.

\section{Criteria of common importance}

Evaluative criteria of common importance are those which are indicated by all the samples in the article to be important (for example: thus being identified as one of the twenty more important criteria). To accommodate readers who want to analyze multiple groups of respondents within one research project, the discussion focuses on three groups of respondents within this section.

If a criterion is identified by two of the samples as important, while the third sample did not perceive the specific criterion as important, the criterion is rejected as a common important criterion. A common criterion, therefore, is a criterion regarded by all three the samples as an important criterion (Bisschoff, 1992: 260-261).

The identified common criteria could also be ranked in order of importance. This is done by a summation of the rank values of each criterion, and criterion with the lowest cumulative value is regarded as the single most important criterion (Du Plessis, 1986; Bisschoff, 1992: 190). The lowest value is the most important value since the ranking values employed are listed in ascending order, starting from one, hence the most important criterion will be ranked as number one.

\section{Determination of common factors}

The common factors are less easily determined. If a common factor was identified by all three samples, this factor is regarded as a 'pure' common factor (Bisschoff, 1992: 263). Factors could, however, also be identified within all three the samples, but with small discrepancies amongst them. Such a factor is regarded as a common, but an 'impure' factor (Bisschoff, 1992: 264). Impure factors are identified by examining the statements loading upon the factors, and a strong correlation between the factors could result in such a factor being identified as 'impure'. An example from Bisschoff (1992: 266-271) the 'Cost of credit' and 'Financial concerns' could explain this phenomenon better. Although the 'Cost of credit' is a financial matter, the perception thereof was clearly related to the credit component only. This factor is, however, fully incorporated by the other sample's perception of 'Financial concerns'. These 'impure' factors are thus also common factors, and should be determined by the analysis. If not, the pitfall of ignoring strong correlations in certain areas between the samples could lead to an incomplete analysis and the outcome could be an incorrect interpretation of the results.

\section{Global correlation coefficients}

The determination of the global correlations between the different samples prove to be important because if the samples do not correlate towards each other in a macro comparison, the determination of the correlations in a micro comparison could prove to be difficult (Botha \& Laas, 1984: 129). For example, if the global correlation between two samples is only $50 \%$, it means that the samples correlate to each other only half the time. The other $50 \%$ is not accounted for (Bisschoff, 1992: 271). The micro analysis, thus the factor analysis, could explain a favourable $60 \%$ of the variance, but the result would be that only $60 \%$ of the correlation between the two samples, thus $50 \%$, would be compared. The result is thus that $60 \%$ of the $50 \%$, which equals $30 \%$ of the correlation between the samples, is effectively compared (Bisschoff, 1992: 185-187).

A high global correlation between the samples is thus essential for meaningful comparative results, derived from the value returned by the global correlation measurement (Statgraphics User's Manual, 1985: 26-15).

The global measurement, called 'Spearman's rank correlation coefficient', is introduced at this stage, and it compares the mean perceptions of each group of the respondents to one another. If the global comparison indicates that a high global correlation exists between the respondent 
groups, the evaluative criteria identified at stage 1 seems to address most of the relevant perceptions of the samples (Statgraphics User's Manual, 1985: 26-15,16; Botha \& Laas, 1984: 128). If not the less important criteria could be identificd by increasing the cut-off factor loading set for the article, and thereby omitting the less significant criteria from the analysis.

\section{Stage 4: Results and findings}

The preceding analysis logically suggests the outcome(s) and results of the marketing research process suggested in this article. The results consist of the more important criteria, the individual factors and a demographic profile for each of the groups of respondents. It also includes this information with regard to the groups of respondents when the individual results are being compared. The global correlation coefficient existing between the samples is also shown.

These results enable the researcher to establish what common ground does exist between the samples, and to what degree the results being described as not so common, do correlate to the other samples (Bisschoff, 1992: 264). This indication could result in a more market directed marketing approach to ensurc increased productivity and more successful sales activities (Rudansky, 1988: 17).

\section{Advantages and criticisms of the research model employed}

The advantages of the research model prescribed in this article resides mainly in the fact that the statistical procedures have been tested in the agricultural tractor market (Bisschoff, 1992), and was found to be a successful approach to conduct marketing research within the agricultural sector. The structuring of the analyses provide a cognitive map to future researchers, and they could monitor the quality of the expected results throughout cach stage of the research model (Bisschoff, 1992: 237). This implies that the researcher could determine, before entering the next stage of the research model, if the results obtained thus far, are of the quality it is expected to be. If not, the feedback supplied in dashed line of Figure 1 directs the researcher towards a previous stage which is to be repeated.

Another advantage is the fact that the model supplies the answers to the problem of evaluating a group of respondents which, for example, act as sellers or marketers of a product in relation to the buyers of that product. Surely, if the sellers know what the buyers perceive as important with regard to a specific produch, they could enhance their sales by concentrating on the more important issues (Rudansky, 1988: 17). The fact that the research model was proven to be successful by Bisschoff (1992), provides the advantage of saving other researchers the time to develop their own agricultural marketing research processes.

A criticism to the structured markcting research model certainly resides in the fact that the first stage is the vital stage with regard to quality results. This stage is however very time consuming since the different role players in a research project seldom agree about the importance of the evaluative criteria. This could mislcad the researcher, and important criteria could be omitted from the initial list of evaluative criteria.

\section{Summary}

The article highlights the agricultural marketing research model employed and indicates that the constructed model could be employed in other relevant research projects. Certainly, such a methodological base supplies a frame of reference to other researchers in the agricultural marketing research discipline.

The article examines the methodological process employed in the four stages within which the process operates. The first stage consists of the determination of the evaluative criteria, and is regarded as a vital stage in the process. The second stage analyzes the individual samples' data and determines the more important criteria, the underlying factors and the demographic profiles of the groups of respondents. The third stage pertains to the comparative analysis of the foregone identified critcria, factors and demographics. It also offers the global correlation coefficient between the samples by means of the technique 'Spearman's rank correlation coefficient'. The final stage refers to the results and findings obtained from the analyses.

Also mentioned in the article are the advantages of the prescribed agricultural marketing research model, and a criticism which could also be regarded as a waming against a serious pitfall within the process is offered.

\section{References}

Bennet, J.A. 1989. 'n Ondersoek na die bemarkings-en verbruikersgerigtheid van die SA hotelbedryf. Ongepubliseerde D.Com proefskrif. Bloemfontein: University of the Orange Free State.

Bennet, J.A. 1992. 'Verbruikersgerigtheid en dienskwaliteit in 'n SA hotelgroep'. Stellenbosch: Bestuursdinamika: Kontemporêre navorsing tydskrif vir die SAIBW, Vol. 1.

Bisschoff, C.A. 1989. Consumer purchasing behaviour in the advanced mechanized irrigation industry. Unpublished M.Com thesis. Pretoria: University of South Africa.

Bisschoff, C.A. 1992. Factor identification in the agricultural tractor industry. Unpublished D.Com thesis. Pretoria: University of South Africa.

Bisschoff, A. \& Marais, A de K. 1993. Identification of underlying dimensions which influence farmer buying behoviour in the advanced mechanized irrigation industry. Budapest. International Farm Management Association: Contributed Papers II.

Botha, J.A.R. \& Laas, A.O. 1984. Gevorderde bemarkingsnavorsing: bemarkingsnavorsing $A$. Pretoria: University of South Africa.

Botha, J.A.R. \& Loubser, F.J. 1984. Gevorderde bemarkingsnavorsing: bemarkingsnavorsing $B$. Pretoria: University of South Africa.

Boyd, H.W., Westfall, R. \& Stash, S.F. 1985. Marketing research. Sixth Edition. Illinois: Irwin.

Coetsee, K. \& Viljoen, M.F. 1990. 'Die ontwikkeling van 'n model vir die ondersteuning van boere by die neem van vervangingsbesluite', Agrekon, Vol. 29, No. 4. 
Du Plessis, P.J. 1986. Aankoop van 'n motorvoertuig. Ongepubliseerde DBL verhandeling. Pretoria: Universiteit van Suid-Afrika.

Du Plessis, P.J. 1987. 'Faktore by die aankoop van 'n motor vir privaatgebruik', S.A. Tydskrif vir Bedryfsleiding, Vol. 18, No. 3.

Hough, J. 1993. 'Die gebruik van hoofkomponent- en profielontledings in strategiese bestuursnavorsing deur 'n graankoßpperasies in SA', Agrekon, Vol. 32, No. 1.

Kienzle, S.W. \& Schultzs, R.E. 1992. 'A simulation model to asses the effect of afforestation on ground-water resources in deep sandy soils', Water SA. Vol.18, No. 4.

Landy, F.J. \& Trumbo, D.A. 1980. Psychology of work behavior. Illinois, Homewood: Dorsey Press:

Laubscher, J.M. 1990. 'Landbou-ekonomic in die RSA na 2', Agrekon, Vol. 29, No. 4.

Le Roux, NJ. \& Olivier, P. 1992. 'Diskriminantanalise en trosanalise as beskrywende tegnieke van finansiële mislukking'. Bestuursdinamika: Kontemporêre navorsing tydskrif vir die SAIBW, Vol. 1.

Luck, D.J., Wales, H.G., Taylor, D.A. \& Rubin, R.S. 1982. Marketing research. Sixth Edition. New Jersey, Englewood Cliffs: Prentice Hall.

Machethe, C.L. 1990. 'Factors contributing to poor performance of agricultural cooperatives in less developed areas', Agrekon, Vol. 29, No. 4.

McGrann. J.M. 1993. Standardized methods for improving farm decisions - production and financial performance standards in ranch management. Budapest: International Farm Management Association; Invited Papers.

Rousseau, G.G. 1992. 'Identifying criteria of consumer awareness in a new South Africa', Bestuursdinamika: Kontemporêre navorsing tydskrif vir die SAIBW, Vol. 1.

Rudansky, S. 1988. 'Consumer behaviour as an instance of risk taking', Dynamica, Vol. XXX.

Stalgraphics User's Manual. 1985. Statgraphics version 1.I. Rockville: Software Publishing Company.

Van der Walt, de la R. 1989. 'An inquiry into inferior and superior role portrayals in multi-racial television advertisements', Communicare: SA Magazine for Communication. Vol. 7, No. 2.

Voros, M. \& Manos, B. 1993. Standardised methods for improving farm decisions - a decision support program for poultry producers. Budapest: International Farm Planagement Association; Invited Papers.

Williams, T.G. 1982. Consumer behavior: fundamentals \& strategies. Los Angeles: West Publishing Company. 